\title{
Moyamoya disease in 4 children from South India
}

\author{
Shravan Kanaparthi ${ }^{1}$, Suneel C Mundkur ${ }^{2}$, Shrikiran Aroor Hebbar ${ }^{3}$, Kalyan Chakravarthy Konda $^{4}$, \\ Girish Menon $^{5}$, Amrita Banerjee ${ }^{6}$
}

Sri Lanka Journal of Health, 2019; 48(3): 266-269

DOI: http://dx.doi.org/10.4038/sljch.v48i3.8766

(Keywords: Moyamoya, cerebrovascular stroke, magnetic resonance angiography)

\section{Introduction}

Moyamoya disease typically refers to an idiopathic form of arteriopathy whereas Moyamoya syndrome refers to cases in which specific angiographic findings are associated with neurofibromatosis, Down syndrome, sickle cell anaemia, head trauma and prior cranial irradiation ${ }^{1}$. In Japan, the incidence and prevalence rates are 0.94 and 10.5 patients per 100,000 people, respectively ${ }^{2}$. We hereby present 4 cases of Moyamoya disease managed at our centre.

\section{Case series}

Clinical details, angiography findings and definitive treatment offered are shown in Table 1.

Table 1: Clinical profile, angiographic findings and surgical treatment offered in the 4 cases of Moyamoya

\begin{tabular}{|c|c|c|l|l|l|}
\hline $\begin{array}{c}\text { Case } \\
\text { No. }\end{array}$ & $\begin{array}{c}\text { Age } \\
\text { (years) }\end{array}$ & Sex & Clinical presentation & \multicolumn{1}{|c|}{$\begin{array}{c}\text { Angiography findings } \\
\text { (MR / Cerebral) }\end{array}$} & Surgical management \\
\hline 1 & 6 & F & $\begin{array}{l}\text { Right upper motor } \\
\text { neuron (UMN) } \\
\text { hemiparesis }\end{array}$ & $\begin{array}{l}\text { MRA - bilateral (B/L) internal } \\
\text { carotid artery (ICA) stenosis } \\
\text { with infarcts in left middle } \\
\text { cerebral artery (MCA) territory. }\end{array}$ & Not done \\
\hline 2 & 13 & F & $\begin{array}{l}\text { Right UMN } \\
\text { hemiparesis }\end{array}$ & $\begin{array}{l}\text { ICA stenosis, hypoplastic left } \\
\text { MCA. }\end{array}$ & $\begin{array}{l}\text { Direct revascularization } \\
\text { procedure (Superior temporal } \\
\text { artery to MCA bypass). }\end{array}$ \\
\hline 3 & 13 & M & $\begin{array}{l}\text { Transient loss of } \\
\text { consciousness with } \\
\text { headache and memory } \\
\text { disturbance. No focal } \\
\text { neurological deficits } \\
\text { were observed. }\end{array}$ & $\begin{array}{l}\text { B/L ICA stenosis and non- } \\
\text { opacification of anterior } \\
\text { cerebral artery (ACA), MCA } \\
\text { with multiple collaterals and } \\
\text { right>left involvement of } \\
\text { posterior cerebral artery (PCA). }\end{array}$ & Not done \\
\hline 4 & 11 & F & $\begin{array}{l}\text { Right UMN } \\
\text { hemiparesis with } \\
\text { slurred speech }\end{array}$ & $\begin{array}{l}\text { Occlusion of B/L supraclinoid } \\
\text { ICA with non-opacification of } \\
\text { ACA, MCA and multiple } \\
\text { collaterals along with multiple } \\
\text { infarcts. Posterior circulation } \\
\text { was involved (stenosis of distal } \\
\text { vertebral artery) }\end{array}$ & $\begin{array}{l}\text { Combined (direct and } \\
\text { indirect) surgical re- } \\
\text { vascularization (STA to MCA } \\
\text { bypass and encephalo-duro- } \\
\text { arterio-myo-synangiosis) } \\
\text { initially on the left followed } \\
\text { by the right side. }\end{array}$ \\
\hline
\end{tabular}

MRA- Magnetic resonance angiography, STA-Superior temporal artery

\begin{abstract}
${ }^{1}$ Assistant Professor, ${ }^{2}$ Additional Professor, ${ }^{3}$ Professor and Head of Department, ${ }^{4}$ Senior Resident, Department of Paediatrics, ${ }^{5}$ Professor and Head of Department, Department of Neurosurgery, ${ }^{6}$ Junior Resident, Department of Paediatrics, Kasturba Medical College, Manipal, Manipal University, Karnataka, India

*Correspondence: k.kalyan.22189@gmail.com

(iD)

orcid.org/ 0000-0001-6738-2910
\end{abstract}

(Received on 16 November 2017: Accepted after revision on 22 December 2017)

The authors declare that there are no conflicts of interest

Personal funding was used for the project.

Open Access Article published under the Creative

Commons Attribution CC-BY (C) (P)
Magnetic resonance angiography (MRA) was done in one case, whereas others underwent cerebral angiography. Angiography findings of each case are shown in Figures 1-4. Evaluation done for predisposing thrombotic conditions was found to be negative in all cases. All 4 children were started on aspirin, but definitive surgical management could be offered for only two children (others had financial constraints). In the 2 children who underwent surgery, no perioperative complications were observed, and both showed improved cerebral circulation at follow-up. 

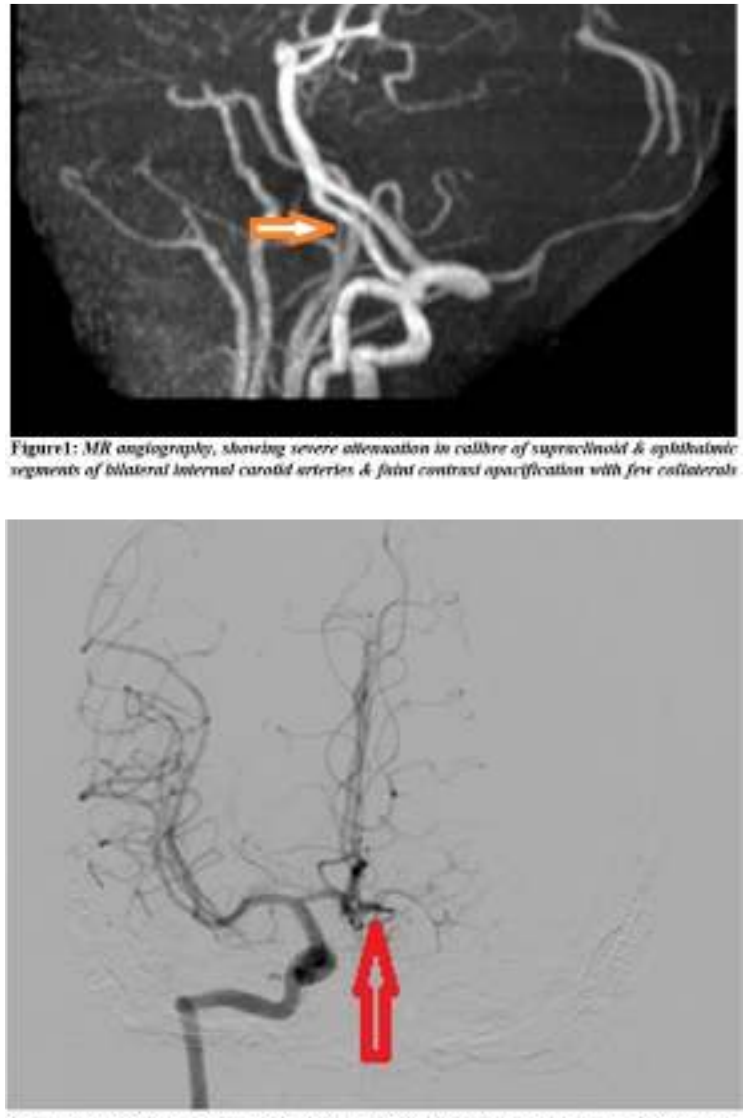

Figure 2: Right internal carotid artery injection showing left anterior cerebral artery (ACA) being filled by collaterals from right ACA
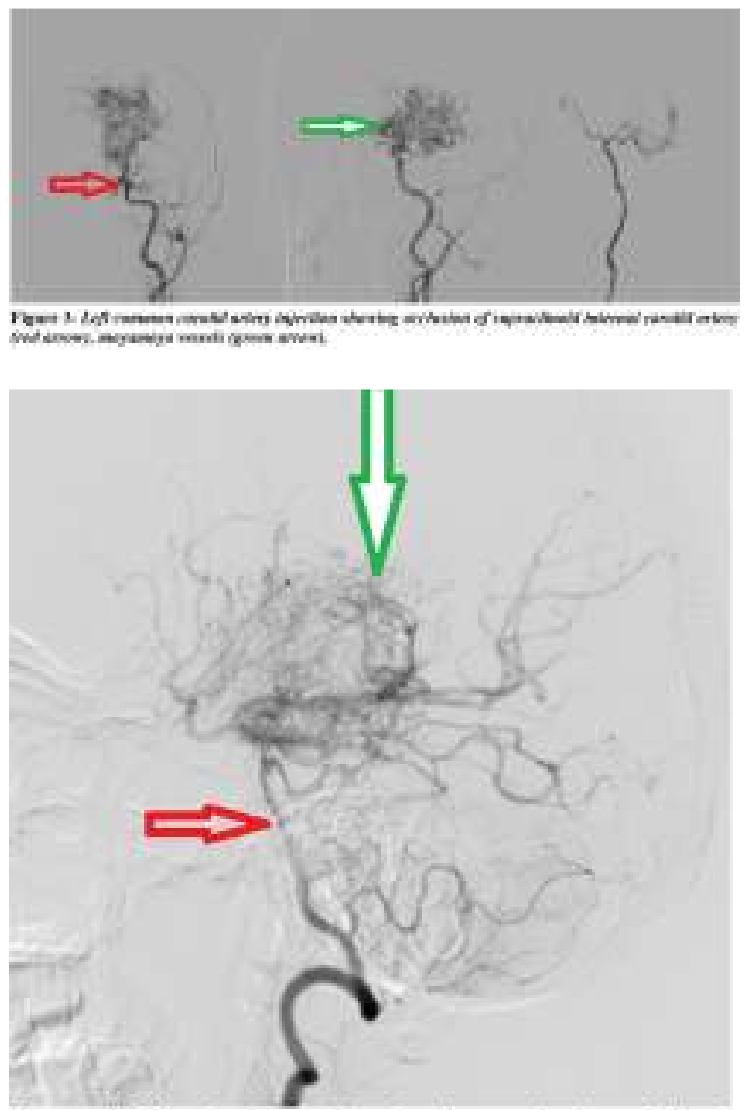

Figure 4: Vertebral injection showing occlusion of distal vertebrat and moyamoya vessets (green arrow)

\section{Discussion}

Moyamoya disease has a bimodal age distribution (5-9 years and 45-49years of age), with a female to male ratio of $2.18^{2}$. In the present study, age ranged between 6-13yrs. Pathogenesis in Moyamoya is unclear. Genetic factors, infective pathogens and inflammatory process are proposed as an underlying mechanism ${ }^{1}$. Ischaemia was more common in younger children (65-78\%) when compared to older children (53\%). The tendency for haemorrhage $(24 \%)$ was higher in older children $^{2}$. Headache, seizures, involuntary movements and cognitive dysfunction are also $\operatorname{seen}^{1,3}$. Posterior circulation can be involved in 24$30 \%$ of cases where they present with visual defects, ataxia or vertigo ${ }^{4}$.

In the present study, three had sudden onset rightsided hemiparesis as the predominant manifestation. One child had transient ischaemic attacks and headache as a manifestation. Two had only anterior cerebral circulation involved whereas others had both anterior and posterior circulation involvement. All children had infarcts at presentation, and none had haemorrhage.

Bilateral involvement of cerebral circulation is more common in Moyamoya. A unilateral presentation is seen in $14 \%$ of cases and among them $30 \%$ progress to bilateral involvement within 2 years, necessitating regular follow-up and neuroimaging. Disease process and clinical symptoms are likely to progress if left untreated leading to neurological deficits with poor functional and intellectual outcome $e^{1,5}$. In the present study, all had bilateral angiographic evidence of stenosis.

Angiography is the gold standard, but as it is invasive, magnetic resonance angiography, which is non-invasive and reliable, is used to assess the cerebral vasculature ${ }^{1,6}$. Single-photon emission computed tomography (SPECT) can be used to evaluate cerebral blood flow ${ }^{1,3}$. Suzuki and Takaku angiographic staging is used to classify patients with Moyamoya disease. This staging indicates intrinsic compensatory re-organisation process of Moyamoya disease ${ }^{8}$. In the present study, cerebral angiography was done in 3 children and MR angiography in the other child. Post-operative regression of vessels can be followed noninvasively with MRI and MRA or with CT angiography.

At present, no medical treatment capable of modifying the natural course of the disease is available. Aspirin (to avoid ischaemic symptoms), steroids and calcium channel blockers (in patients with recurrent postoperative transient ischaemic attacks and intractable headache) were used in a 
few cases ${ }^{3}$. Surgical correction involves creating an anastomosis and thereby re-vascularisation of the affected area. They are of three types: Direct, Indirect and combined. Direct bypass technique involves anastomosis between the superficial temporal artery and either MCA or ACA. It provides immediate re-vascularisation and has a lesser chance of peri-operative stroke risk. Sudden restoration of blood flow may lead to postoperative hyper-perfusion syndrome necessitating close vigilance $^{8}$. It is technically challenging in children due to the fragile and smaller vessels when compared to adults ${ }^{1,3}$.

Indirect bypass techniques are technically simpler, more commonly done in the paediatric population ${ }^{10}$ and include pial-synangiosis, encephalo-duroarterio-synangiosis (EDAS), encephalo-myosynangiosis (EMS), encephalo-myo-arteriosynangiosis (EMAS), encephalo-duro-arterio-myosynangiosis (EDAMS), encephalo-duro-myoarterio-pericranial synangiosis, encephalo-galeosynangiosis (EGS) and multiple burr hole surgery. Collateral development is delayed and may take up to 3-4 months with a potential risk of perioperative ischaemic stroke ${ }^{10}$. There is no clinical evidence demonstrating which of the above indirect techniques is more effective; however, EMAS is preferred when feasible. Procedures combining both direct and indirect bypass have the advantages of both methods. In general, older children and adults are offered direct anastomosis, whereas in infants and young children indirect bypass techniques are preferred, however, the final decision has to be individualised. Surgical treatment before the onset of symptoms conferred a good prognosis ${ }^{3}$. In the present study, 50\% (2 out of 4) underwent a surgical procedure. One child was treated with direct bypass technique between STA and MCA. Another child underwent a combined technique bilaterally with bypass between STA and MCA along with EDAMS. Both had no significant post-operative complications with excellent restoration of cerebral blood flow.

Untreated, the disease is likely to progress in $1 / 3 \mathrm{rd}$ cases with recurrent ischaemic events with poor functional and intellectual outcomes. Prior cranial irradiation, congenital cardiac anomaly, Asian ancestry and family history conferred a higher risk for progression ${ }^{6}$. Early onset of symptoms $(<5$ years), completed stroke, cerebral infarction, small craniotomy surgery (EMS, EDAS) and longer disease duration are poor prognostic factors for intellectual outcome. Recurrent haemorrhagic stroke is more common in adults who are treated conservatively ${ }^{1}$.

\section{References}

1. Kuroda S, Houkin K. Moyamoya disease: current concepts and future perspectives. Lancet Neurology 2008; 7(11): 1056-66. https://doi.org/10.1016/S14744422(08)70 240-0

2. Baba T, Houkin K, Kuroda S. Novel epidemiological features of moyamoya disease. Journal of Neurology, Neurosurgery and Psychiatry 2008; 79(8): 900-4.

https://doi.org/10.1136/jnnp.2007.130666

PMid: 18077479

3. Smith JL. Understanding and treating moyamoya disease in children. Neurosurgical Focus 2009; 26(4): E4. PMid: 19335128

4. Miyamoto S, Kikuchi H, Karasawa J, Nagata I, Ihara I, Yamagata S. Study of the posterior circulation in moyamoya disease. Part 2: Visual disturbances and surgical treatment. Journal of Neurosurgery 1986; 65(4): 454-60. https://doi.org/10.3171/jns.1986.65.4.0454 PMid: 3760953

5. Smith ER, Scott RM. Progression of disease in unilateral moyamoya syndrome. Neurosurgical Focus 2008; 24(2):E17. https://doi.org/10.3171/FOC/2008/24/2/E1 7

PMid: 18275294

6. Fukui M. Guidelines for the diagnosis and treatment of spontaneous occlusion of the circle of Willis ('moyamoya' disease). Research Committee on Spontaneous Occlusion of the Circle of Willis (Moyamoya Disease) of the Ministry of Health and Welfare, Japan. Clinical Neurology and Neurosurgery 1997; 99(2):238-40.

https://doi.org/10.1016/S03038467(97)00 082-6

7. Suzuki J, Takaku A. Cerebrovascular "moyamoya" disease: Disease showing abnormal net-like vessels in base of brain. Archives of Neurology 1969; 20(3):28899.

https://doi.org/10.1001/archneur.1969.004

80090076012

PMid: 5775283 
8. Fujimura M, Kaneta T, Mugikura S, Shimizu $H$, Tominaga $T$. Temporary neurologic deterioration due to cerebral hyperperfusion after superficial temporal artery-middle cerebral artery anastomosis in patients with adult-onset moyamoya disease. Surgical Neurology 2007; 67(3):273-82.

https://doi.org/10.1016/j.surneu.2006.07.0 17

PMid: 17320638

9. Fung L-WE, Thompson D, Ganesan V. Revascularisation surgery for paediatric moyamoya: a review of the literature. Child's Nervous System 2005; 21(5):35864.

https://doi.org/10.1007/s00381-004-11189

PMid: 15696334

10. Kuroda S, Houkin K. Moyamoya disease : current concepts and future perspectives. Lancet Neurology 2017; 7(11):1056-66. https://doi.org/10.1016/S14744422(08)70 240-0 